\title{
Comparison of different methods involved in the planning of clinical crown lengthening surgery
}

\section{Fabricio Batistin Zanatta ${ }^{(a)}$ Bruno Rodrigues Giacomelli(a) Patricia Pasquali Dotto(a) Vânia Regina Camargo Fontanella ${ }^{(b)}$ Cassiano Kuchenbecker Rösing ${ }^{(c)}$}

(a) Centro Universitário Franciscano (UNIFRA), Santa Maria, RS, Brazil.

(b) Universidade Luterana do Brasil (ULBRA), Canoas, RS, Brazil.

(c) Universidade Federal do Rio Grande do Sul (UFRGS), Porto Alegre, RS, Brazil.
Corresponding author:

Fabricio Batistin Zanatta

R. Tiradentes, 76, apto. 801 - Centro

Santa Maria - RS - Brazil

CEP: $97050-730$

E-mail: fabriciobzanatta@yahoo.com.br

Received for publication on Jun 22, 2010 Accepted for publication on Sep 20, 2010

\begin{abstract}
There is little material in the literature that compares biological width measurements in periapical and bite-wings radiographs with clinical measurements. The purpose of this study was to compare measurements of biological width taken by three different methods which are frequently used for planning periodontal surgery - periapical radiograph, bite-wing radiograph and transperiodontal probing - with the trans-surgical measurements. Thirty-four sites from twenty-one subjects were analyzed. The intra-class correlation coefficients between measurements obtained trans-surgically (gold standard) and those obtained by transperiodontal probing, periapical radiography and bite-wing radiography were determined. Average measurements were compared using the Wilcoxon test at a significance level of 0.05 . Also, the frequency distribution of differences between test measurements and the gold standard was calculated. The results showed that transperiodontal probing (mean $2.05 \mathrm{~mm}$ ) was the most accurate measurement, as compared to the gold standard (mean $1.97 \mathrm{~mm}$ ), with no statistically significant difference observed. On the other hand, periapical and bite-wing radiographic mean values $(1.56 \mathrm{~mm}$ and $1.72 \mathrm{~mm}$, respectively) were smaller than the gold standard, with statistically significant differences $(\mathrm{p}<0.05)$. It was concluded that transperiodontal probing was the most accurate measurement, as compared to the gold standard, followed by that obtained with the bite-wing radiograph. The clinical relevance of these results could be that planning for crown lengthening surgery should, preferably, include transperiodontal probing.
\end{abstract}

Descriptors: Periodontics; Planning Techniques; Crown Lengthening; Surgery, Oral; Radiology.

\section{Introduction}

When planning clinical crown lengthening (CCL) surgeries, it is necessary to observe if the periodontal biological width has been infringed. This width comprises the distance between the bottom of the histological gingival sulcus and the alveolar bone crest, disregarding the histological epithelium, since it can be included in prosthetic and restorative procedures. ${ }^{1}$

A classic study by Gargiullo et al. ${ }^{2}$ measured these distances in human autopsies and obtained the following mean distances for periodontal biological width: histological sulcus $(0.69 \mathrm{~mm})$, junctional epithe- 
lium $(0.97 \mathrm{~mm})$, and connective tissue attachment $(1.07 \mathrm{~mm})$, which, in total, comprise $2.73 \mathrm{~mm}$. Additional evidence, obtained with similar methodology, confirmed these findings with small variations. ${ }^{3-6}$ However, it has been understood that these values involved a high degree of variation among subjects. ${ }^{4}$

It has been argued that disturbance of biological width by restorations may result in chronic inflammation, pocket installation and, eventually, in attachment loss and bone resorption.-9 ${ }^{7-9}$ Therefore, CCL has been indicated in order both to prevent the inflammatory reaction and to allow for correct restorative/prosthetic technical procedures.

Taking into consideration the possible problems linked to the disturbance of biological width, it is important that an accurate diagnostic method be applied. According to Reed and Polson, ${ }^{11}$ bite-wing radiographs are probably the best for establishing an accurate radiographic scenario of alveolar bone height. On the other hand, parallel periapical radiographs seem better for determining the extent of the level of all the periodontal bone. Some studies suggested that radiographs tend not to be accurate, and that different radiographic techniques should be studied for their accuracy. ${ }^{12-14}$ Additionally, a clinical method has been proposed: transperiodontal probing, which could avoid radiation exposure and provide more precision.

The clinical applicability of this information is twofold:

1. it indicates when biological width is infringed, and

2. it allows more precise planning of the surgical procedure, i.e., if there is need or not to assess the alveolar bone (in order to perform osteotomy).

Therefore, the aim of this study was to compare three different methods for diagnosing the invasion of periodontal biological width - periapical radiography, bite-wing radiography and transperiodontal probing - with the real surgical measurements. The hypothesis to be tested is that transperiodontal probing is at least as accurate as the radiographic measurements, compared to surgical measurement.

\section{Materials and Methods}

The sample for the present study comprised twenty-one eligible participants, from a total of thirty-six initially screened subjects, ranging between 21 and 60 years of age (mean age $41 \pm 10.68$ ) and referred for CCL surgery at the Dental School of the Franciscan University Center, in Brazil. The research protocol was approved by the Ethical Committee of the Franciscan University Center (CONEP: Number 1246 / CEP/UNIFRA: Number: 078.20082).

Inclusion criteria: The participating subjects should be over 18 years, have need of CCL in an interproximal site with probable osteotomy, in order to allow adequate restorative rehabilitation.

Exclusion criteria: The subjects with generalized periodontal inflammation, those who exhibited a systemic condition that contraindicated the surgical procedure, and individuals who did not agree to sign the consent form were excluded from the study.

After inclusion, individuals underwent CCL surgery. Following the removal of all carious tissue (if necessary), in order to determine the real terminus of sound dental tissue, two radiographs were taken for each area involved: 1 (one) periapical radiograph was taken using the bisecting-angle technique, and 1 (one) bite-wing radiograph.

All radiographs were taken by the same examiner, using radiographic indicators (Indusbello ${ }^{\circledR}$, Londrina, Paraná, Brazil) and an X-ray machine (Dabi Atlante ${ }^{\circledR}$ Spectro 70X, Ribeirão Preto, São Paulo, Brazil), with exposure time of $0.4 \mathrm{~s}$ in both upper and lower jaws. Periapical type films (Kodak ${ }^{\circledR}$ Insigth, Manaus, Amazonas, Brazil) were used, and processing was accomplished manually, employing unused chemical substances and following the timetemperature table in order to standardize the radiographs for the measurements.

Next, the surgical procedure was performed. After giving local anesthesia, the transperiodontal measurement was obtained. This involved taking a measurement at the site of the tooth that supposedly needed osteotomy, using a $10 \mathrm{~mm}$ periodontal probe (Neumar ${ }^{\circledR}$, Caieiras, São Paulo, Brazil) with a $0.5 \mathrm{~mm}$ diameter and rhombus tip end, until reaching the alveolar bone. In this measurement, the distance from the most apical portion of the tooth's cavity/defect to the interproximal bone crest was 
obtained.

A modified Widman flap was elevated, soft tissue (gingiva and granulation) was removed, the root surfaces were planed and the wound was rinsed with saline. The trans-surgical measurement of the distance from the most apical portion of the proximal cavity/defect to the bone crest was then performed. Next, the routine surgery was carried out with osteotomy according to the necessity, sutured, and concluded with post-operative instructions.

\section{Radiographic measurements}

Each periapical and bite-wing radiograph was analyzed in an X-ray illuminator covered by a black paper. This was used in order to concentrate all the light of the device onto the radiograph to be analyzed. Using a digital caliper (Jomarca, Stainless Hardened ${ }^{\circledR}$, Nieuw, Vennep, Netherlands) the measurement from the most apical portion of the proximal defects/cavities to the bone crest was made using the periapical and bite-wing radiographs. All clinical and radiographic measurements were made by the same examiner.

\section{Pre-experimental training and calibration}

Prior to making the radiographic measurements, the examiner attended a training session given by an oral radiologist for the measurement of the periapical and bite-wing radiographs. Calibration was subsequently carried out using 10 periapical and 10 bite-wing radiographs. Finally, agreement between the measurements of the same radiographs was obtained at two different time-points (2-week interval) and compared using the intraclass correlation coefficient (Table 1).

Regarding the trans-surgical and transperiodontal measurements, one trained examiner made the measurements; however, calibration figures were calculated.

Table 1 - Intra-examiner calibration to the radiograph measures.

\begin{tabular}{c|c|c}
\hline Radiograph & $\mathrm{n}$ & Intra-class correlation coefficient \\
\hline Periapical & 10 & 0.87 \\
\hline Bite-wing & 10 & 0.96 \\
\hline
\end{tabular}

\section{Statistical Analysis}

Mean values of radiographic measurements, taken from periapical and bite-wing radiographs, as well as the measurements obtained by transperiodontal probing, were obtained and compared with those of the trans-surgical measurements (gold standard) using the Wilcoxon signed test at a .05 level of significance. The intraclass correlation coefficient among the measurements obtained with the three test methods and the gold standard was also calculated.

\section{Results}

The mean age of the 21 patients included in the study was 41 years-old $( \pm 10.68)$. Table 2 shows the distribution of teeth and surfaces examined in the present study. It can be observed that the 34 teeth evaluated comprised 32 molars and 2 premolars. Regarding tooth surfaces, the sample comprised 19 distal and 15 mesial surfaces.

The results of the comparison among the mean values of the measurements obtained by transperiodontal probing, and from periapical and bite-wing radiographs in relation to the trans-surgical measurements (gold standard) are shown in Table 3. Also, correlations of each method, compared to the gold standard, are demonstrated. It was observed that the mean trans-surgical measurement (gold standard) was $1.97 \mathrm{~mm}$. Statistically significant differences were observed when all measurements were compared to the gold standard. The mean closest to this measurement was the transperiodontal assessment $(2.05 \mathrm{~mm})$. When the intraclass correlation coefficient was calculated, transperiodontal measurement was the most accurate as compared to the trans-surgical assessment, followed by the bite-wing and periapical measurements, respectively.

Table 2 - Absolute and percentage distribution of the teeth and sites evaluated.

\begin{tabular}{c|c|c|c|c}
\hline \multicolumn{2}{c|}{} & \multicolumn{2}{c|}{ Teeth } & \multirow{2}{*}{ Total (\%) } \\
\cline { 2 - 5 } \multicolumn{2}{c|}{} & Molar & Pre-molar & \\
\hline \multirow{3}{*}{ Sites } & Distal & 19 & 0 & $19(56 \%)$ \\
\cline { 2 - 5 } & Mesial & 13 & 2 & $15(44 \%)$ \\
\cline { 2 - 5 } & Total (\%) & $32(94 \%)$ & $2(6 \%)$ & $34(100 \%)$ \\
\hline
\end{tabular}


Table 3 - Descriptions and Correlations between clinical and radiographic measures compared to the gold standard (Trans-surgical measure).

\begin{tabular}{|c|c|c|c|c|c|}
\hline Methods & $\begin{array}{c}\text { Mean } \pm \text { SD } \\
\mathrm{Cl} 95 \% \text { of mean (lower - upper) }\end{array}$ & $\begin{array}{l}\text { Median } \\
\text { (P25-P75) }\end{array}$ & $A \times D$ & $B \times D$ & $C \times D$ \\
\hline Transperiodontal (A) & $\begin{array}{l}2.05 \pm 0.94^{\times *} \\
(1.73-2.38)\end{array}$ & $\begin{array}{c}2.00 \\
(1.68-2.5)\end{array}$ & \multirow{4}{*}{$0.92 \#$} & \multirow{4}{*}{0.61} & \multirow{4}{*}{0.84} \\
\hline Periapical (B) & $\begin{array}{l}1.56 \pm 0.90^{\top *} \\
(1.18-1.86)\end{array}$ & $\begin{array}{c}1.62 \\
(0.89-2.32)\end{array}$ & & & \\
\hline Bite-wing $(\mathrm{C})$ & $\begin{array}{l}1.72 \pm 0.85^{W *} \\
(1.32-2.00)\end{array}$ & $\begin{array}{c}1.85 \\
(1.12-2.24)\end{array}$ & & & \\
\hline Trans-surgical (D) & $\begin{array}{l}1.97 \pm 0.96^{\Upsilon *} \\
(1.63-2.30)\end{array}$ & $\begin{array}{c}2.00 \\
(1.37-2.50)\end{array}$ & & & \\
\hline
\end{tabular}

*Different letters show statistically significant differences by the Wilcoxon signed test $(p<0.05)$. \#Intra-class correlation coefficient between clinical and radiographic measurements compared to gold standard.

Table 4 - Frequencies of differences between clinical and radiographic measures compared to the gold standard (Trans-surgical).

\begin{tabular}{c|c|c|c}
\hline $\begin{array}{c}\text { Differences } \\
\text { In millimeters }\end{array}$ & $\begin{array}{c}\text { Transperiodontal } x \\
\text { Trans-surgical } \\
\mathrm{n}(\%)\end{array}$ & $\begin{array}{c}\text { Bite-wing } \mathrm{x} \\
\text { Trans-surgical } \\
\mathrm{n}(\%)\end{array}$ & $\begin{array}{c}\text { Periapical } \mathrm{x} \\
\text { Trans-surgical } \\
\mathrm{n}(\%)\end{array}$ \\
\hline 0 & $18(53 \%)$ & $3(8.8 \%)$ & 0 \\
\hline $0.1-0.5$ & $16(47 \%)$ & $19(55.9 \%)$ & $16(47 \%)$ \\
\hline $0.6-1.0$ & 0 & $11(32.4 \%)$ & $12(35.4 \%)$ \\
\hline $1.1-1.5$ & 0 & 0 & 0 \\
\hline $1.6-2.0$ & 0 & 0 & $1(14.7 \%)$ \\
\hline$>2$ & 0 & $1(2.9 \%)$ & 1 \\
\hline
\end{tabular}

Table 4 shows the means and frequencies of the differences found between each method and the gold standard. It can be observed that there were no differences between the mean transperiodontal measurements and the gold standard in $53 \%$ of the sites, and that the difference ranged between $0.1 \mathrm{~mm}$ and $0.5 \mathrm{~mm}$ in $47 \%$ of the sites. On the other hand, there were no differences between the bite-wing and gold standard measurements in only $8.8 \%$ of the sites, while $55.9 \%$ differed by at most $0.5 \mathrm{~mm}$, $32.4 \%$ by at most $1 \mathrm{~mm}$, and $2.9 \%$ by more than $2 \mathrm{~mm}$. Finally, none of the periapical measurements coincided with the gold standard, and differences of up to $0.5 \mathrm{~mm}, 1 \mathrm{~mm}, 1.5 \mathrm{~mm}$, and of more than $2 \mathrm{~mm}$ were observed in $47 \%, 35.4 \%, 14.7 \%$ and $2 \%$ of sites, respectively.

\section{Discussion}

The present study clearly demonstrated that the diagnostic measurement closest to the real measurement (gold standard) was the transperiodontal probing. This approach exhibited the highest frequency of measurements coincident with the gold standard.
Furthermore, when the measurements differed, these differences were not greater than $.5 \mathrm{~mm}$ and the intra-class correlation coefficient was 0.92 , very close to a perfect agreement. Transperiodontal probing has not been a widely used method, especially taking into consideration that it requires local anesthesia. However, once the necessity for surgery is determined, the dentist can take advantage of either the previous anesthesia, for removing the carious tissue (when necessary); or even, the anesthesia administered prior to the surgery. This would certainly allow for better planning of the surgical procedure. Festugatto et al. ${ }^{13}$ presented results similar to the ones found in this study. Their results indicated greater accuracy for probing as compared to the radiographs. However, the periapical radiographs in the study by Festugatto et al. ${ }^{13}$ were periapical with parallelism. It should be noted that this radiograph is not widely used in clinical practice, and the present study analyzed radiographic approaches which are more frequently used in clinical practice. Other studies, with different objectives, also compared clinical to radiographic situations and have reported 
observations that the radiograph normally underestimates bone loss as compared to the clinical situation. ${ }^{15-20}$

On the other hand, in cases where proximal cavities in adjacent teeth are present, transperiodontal probing could be difficult to perform. In this way, radiographs may help with diagnosis and planning. However, radiographs themselves have the limitation of two-dimensional representation of a threedimensional structure, which can distort the real measurements to be analyzed. In this study, the means of both types of radiographic measurements showed statistically significant differences when compared to the gold standard by underestimating it. From a clinical point of view, this means that the biological width of the periodontium would be shown as being invaded by the restoration and CCL, with osteotomy frequently indicated; yet in fact, the surgical procedure either would not be needed, or at least could be limited to soft tissues. Nevertheless, the bite-wing radiographic measurement was far closer to the gold standard than the periapical radiographic measurement. This was detected by the comparison of means, frequency distribution of differences and in the intraclass correlation coefficient.

These findings were corroborated by Pimentel et al. ${ }^{14}$ who compared bite-wing and periapical radio-

\section{References}

1. Bragger U, Lauchenauer D, Lang NP. Surgical lengthening of the clinical crown. J Clin Periodontol. 1992 Jan;19(1):58-63.

2. Gargiulo AW, Wentz FM, Orban B. Mitotic activity of human oral epithelium exposed to 30 per cent hydrogen peroxide. Oral Surg Oral Med Oral Pathol. 1961 Apr;14(4):474-92.

3. Ingber JS, Rose LF, Coslet JG. The "biologic width"--a concept in periodontics and restorative dentistry. Alpha Omegan. 1977 Dec;70(3):62-5.

4. Tarnow DP, Magner AW, Fletcher P.The effect of the distance from the contact point to the crest of bone on the presence or absence of the interproximal dental papilla. J Periodontol. 1992 Dec;63(12):995-6.

5. Tristão GC. Espaço biológico: Estudo histométrico em periodontia clinicamente normal em humanos [tese]. São Paulo: Universidade de São Paulo, Faculdade de Odontologia; 1992. $57 \mathrm{p}$. graphic measurements to trans-surgical measurements, and found the highest distortions for the periapical method. This fact could be explained due to the use of the bisecting-angle technique, where the bone crest is projected in the oclusal/incisal direction, resulting in an overestimation of the invasion of biological width. Other studies, that compared bite-wing and periapical radiographs, also reported similar results. ${ }^{12,20,22}$

\section{Conclusions}

Taking into consideration the design of the present study, it can be concluded that none of the methods employed reproduce the trans-surgical measure exactly. However, transperiodontal probing exhibited the best results, followed by the bite-wing and periapical radiographs, respectively. Therefore, for diagnosis of the invasion of biological width and surgical planning, transperiodontal probing is recommended.

\section{Acknowledgements}

The authors wish to thank the volunteers who participated in this research. Drs. Zanatta, Dotto, Giacomelli, Fontanella and Rösing report no conflicts of interest related to this study.

6. Vacek JS, Gher ME, Assad DA, Richardson AC, Giambarresi LI. The dimensions of the human dentogingival junction. Int J Periodontics Restorative Dent. 1994 Apr;14(2):154-65.

7. Valderhaug J, Birkeland JM. Periodontal conditions in patients 5 years following insertion of fixed prostheses. Pocket depth and loss of attachment. J Oral Rehabil. 1976 Jul;3(3):237-43.

8. Schätzle M, Land NP, Anerud A, Boysen H, Bürgin W, Löe $\mathrm{H}$.. The influence of margins of restorations on the periodontal tissues over 26 years. J Clin Periodontol. 2001 Jan;28(1):5764.

9. Padbury JA, Elber R, Wang HL. Interactions between the gingiva and the margin of restorations. J Clin Periodontol. 2003 May;30(5):379-85.

10. Gomes SC, Miranda LA, Soares I, Oppermann RV. Clinical and histologic evaluation of the periodontal response to restorative procedures in the dog. Int J Periodontics Restorative Dent. 2005 Feb;25(1):39-47. 
11. Reed BE, Polson AM. Relationships between betwing and periapical radiographs in assessing crestal alveolar bone levels. J Periodontol 1984 Jan;55(1):22-7.

12. Miranda DAO, Gomes Filho IS, Trindade SC, Flores PSC, Rodrigues CL, Miranda CB, et al. Avaliação da distância entre a junção cemento-esmalte e a crista óssea alveolar no estudo comparativo das técnicas radiográficas interproximal e periapical do paralelismo. Rev Periodontia 1999 Jul-Set;11(2): 25-32.

13. Festugatto FE, Daudt FARL, Rösing CK. Aumento de coroa clínica: comparação de técnicas de diagnóstico de invasão do espaço biológico do periodonto. Rev Periodontia. 2000 JanJun;13(1):42-9.

14. Pimentel JO, Filho AMMF, Mota OML, Pereira SLS, Lima DLFL, Carlos MX. Estudo comparativo entre a avaliação radiográfica e transcirurgica no diagnóstico da invasão do espaço biológico periodontal. Rev Periodontia. 2006 Jan-Jun;16(1):11-15.

15. Sonick M. Esthetic crown lengthening for maxillary anterior teeth. Compend Contin Educ Dent. 1997 Aug;18(8):807-12.

16. Ziada H, Irwin C, Mullally B, Byrne PJ, Allen E. Periodontics: 5. Surgical crown lengthening. Dent Update. 2007 Oct;34(8):462-4.
17. Lee EA. Aesthetic crown lengthening: classification, biologic rationale, and treatment planning considerations. Pract Proced Aesthet Dent. 2004 Nov-Dec;16(10):769-78; quiz 780.

18. Merigo CR. Análise radiográfica dos níveis ósseos interproximais em radiografias periapicais convencionais e periapicias milimetradas: Um estudo comparativo [dissertação]. Canoas: Universidade Luterana do Brasil, Curso de Odontologia, 1998. $63 \mathrm{p}$.

19. Eickholz P, Kim TS, Benn DK, Staehle HJ. Validity of radiographic measurement of interproximal bone loss. Oral Surg Oral Med Oral Pathol Oral Radiol Endod. 1998 Jan;85(1):99106.

20. Kiliç AR, Efeoglu E, Yilmaz S, Orgum T. The relationship between probing bone loss and standardized radiographic analysis. Periontal Clin Investig. 1998 Jan;20(1):25-32.

21. Reed BE, Polson AM. Relationships between bitewing and periapical radiographs in assessing crestal alveolar bone levels. J Periodontol. 1984 Jan;55(1):22-7

22. Gomes Filho IS, Miranda DAO, Trindade SC, Costa NO, Macedo TCN. Emprego de dois métodos digitais na análise da distância entre a junção cemento-esmalte e a crista óssea alveolar em exames radiográficos interproximais. Rev Periodontia. 1999 Jan-Jun;8(1): 64-71. 